\section{Regulatory disincentives}

SIR - The report by Bragg et al. describing the effectiveness of bioremediation for the 1989 Exxon Valdez oil spill in Prince William Sound, Alaska, is both cogent and potentially useful ${ }^{1}$. However, the actual bioremediation techniques employed represent science and technology worthy of the nineteenth century. Many biological scientists, particularly those within the 'biotechnology' community, must echo the sentiments of Mr William Reilly, who was the administrator of the US Environmental Protection Agency (EPA) at the time of the incident: "when I saw the full scale of the disaster in Prince William Sound in Alaska ... my first thought was: where are the exotic new technologies, the products of genetic engineering, that can help us clean this up?"2

For the most part, innovative products of the new biotechnology for bioremediation remain on the drawing board, with researchers and companies intimidated by regulatory barriers and disincentives. In the United States, for example, the EPA has tried unsuccessfully for a decade to articulate a final policy on field trials with microorganisms - including those for bioremediation - but has returned again and again to proposals that discriminate against microorganisms created with highprecision rDNA technology while exempting research organisms crafted with any other technique. Indeed, because it is anticipated that, for the foreseeable future, regulatory submissions for bioremediation research on rDNAmanipulated microorganisms will require "excessive time, money and paperwork", and because of the uncertainty of ever obtaining a licence, the US bioremediation industry has largely restricted itself to work with naturally occurring organisms ${ }^{2}$. But because of the nature and complexity of the subtances involved in most spills and toxic wastes, naturally occurring organisms seem not to be up to the job.

The regulatory climate is no better outside the United States. For example, the European Union (EU)'s regulatory approach was taken to task as regressive and anti-innovative in the October 1993 report of the UK House of Lords Select Committee on Science and Technology, Regulation of the United Kingdom Biotechnology Industry and Global Competitiveness ${ }^{3}$. Echoing other assessments of the EU's environmental biotechnology policies, the report recommended reduced and rationalized regulation, concluding that: "As a matter of principle, GMO [genetically manipulated organism]-derived products should be regulated according to the same criteria as any other product . . . U.K. regulation of the new biotechnology (according to EU directives) of genetic modification is ex- cessively precautionary, obsolescent, and unscientific. The resulting bureaucracy, cost, and delay impose an unnecessary burden to academic researchers and industry alike."3

Regulatory disincentives are potent. Until governments demonstrate rationality and sensitivity to scientific principles in their regulatory policies toward the new biotechnology, we'll be slopping bacterial growth media on the beach instead of putting high technology of work.

\section{Henry I. Miller}

Hoover Institution Institute

for International Studies,

Stanford University,

Stanford, California 94305-6010, USA

1. Bragg, J. R., Prince, R. C., Harner, E. J. \& Atlas, R. M. Nature 368, 413-418 (1994).

2. Day, S.M. Trends Biotech. 11, 324-28, (1993).

3. Ward, M. Bio/Technology 11, 1213 (1993).

\section{Health research}

SIR - I should like to clarify a point in David Dickson's report about research supported by the UK National Health Service (Nature 369, 514; 1994). The teaching element of the Service Increment for Teaching and Research (SIFTR) related to student numbers generally "works well", although the sums involved may be insufficient. The Council of Deans agreed recently, however, that the $\mathrm{R}$ element should be separated from the $\mathrm{T}$ and be allocated in relation to research quantity and quality. The deans' concern was that the $\mathrm{R}$ element, designed to support the research infrastructure of university hospitals essential to a wide range of clinical and health services research, might be transferred either to purchasers of health services or to the currently insufficiently funded Health Services Research programme, which would 'rob Peter to pay Paul' and greatly damage the research capability of university hospitals.

\section{Peter Richards}

(Dean)

St Mary's Hospital Medical School,

Norfolk Place, London W2 1PG, UK

\section{Re-setting the great count}

SIR - Emiliani ${ }^{1}$ proposed to solve the problems with our calendar by starting a new count at the beginning of the Holocene, specifically by establishing the birth of Christ as the year 10,000. But one might just as well set the death of Buddha or the Hegira of Mohammed at the year 10,000 and gain other valid and artificially exact starts to the Holocene. Emiliani therefore fails to address one concern he raised himself: that marking time using the event of Christ's birth has no significance for many of the world's cultures.

I have a different solution ${ }^{2}$. No past event (the birth of Christ, the death of Buddha, the Woodstock Rock Festival) can fill the requirement of being truly global. A new calendar must await, therefore, some future moment, as only recently have the world's peoples been sufficiently linked to have such an experience. What could it be? A great war? An asteroid impact? I propose a more positive possibility: When the world is ready it could agree to re-set the count (for example, through a vote in the United $\mathrm{Na}$ tions). This itself would be of sufficient historic importance to kick off the new year number one - the united agreement to start would be the event implicitly celebrated ever after by the new calendar. TylerVolk

Earth Systems Group,

New York University.

34 Stuyvesant Street,

New York, NY 10003-7599, USA

1. Emiliani. C. Nature 366. 716 (1993).

2. Volk, T. Metapatterns across Space, Time, and Mind (Columbia University Press, in the press).

\section{Out of tune}

SIR - Writing from San Diego (Nature 369, 270; 1994), Lawrence Bruton calls for a more logical system of nomenclature in membrane biology. If his proposed scheme is adopted, he concludes, 'dotriacontahectaspan' will roll off the tongue as readily as 'hemisemidemiquaver'. But the correct word in the United Kingdom is 'hemidemisemiquaver', and the United States already has a more logical system of nomenclature in music, giving 'sixtyfourth-note'. For biomusicians this casts doubt on all that went before.

Peter B. Soul

51 Lakeside,

Earley, Reading, Berks RG6 2PG, UK

\section{Long on authors}

SIR - Writing on "making [scientific] publications more respectable" (Nature $\mathbf{3 6 9}, 353 ; 1994)$, you suggested that every co-author of a paper should, in principle at least, be able to give a brief public talk on the substance thereof. The first article of this same issue of Nature (2 June), if I counted correctly, had 108 authors. The public forum that puts this suggestion to the test is going to be a lengthy one.

\section{Beverly Griffin}

Department of Virology,

Royal Postgraduate Medical School,

Du Cane Road,

London, W12 ONN, UK 